RASĀYAN J. Chem.

Vol. 13 | No. 4 |2569-2576| October - December | 2020 ISSN: 0974-1496 | e-ISSN: 0976-0083 | CODEN: RJCABP

\title{
ANTIOXIDANT AND ANTIHYPERURICEMIC POTENTIALS OF RARU (Cotylelobium melanoxylon Pierre) BARK
}

\author{
M. Zulham Efendi Sinaga ${ }^{1,3, *}$, Arida Susilowati ${ }^{2}$, Firman Sebayang ${ }^{1}$, \\ Saraswaty E. Br Ginting ${ }^{1}$ and Tati Suhartati ${ }^{4}$ \\ ${ }^{1}$ Department of Chemistry, Faculty of Mathematics and Natural Sciences, Universitas Sumatera \\ Utara, Jl. Bioteknologi No. 1, Kampus USU - Padang Bulan, Medan, 20155-Indonesia \\ ${ }^{2}$ Faculty of Forestry, Universitas Sumatera Utara, Jl. Tri Dharma Ujung No. 1, Kampus USU- \\ Padang Bulan, Medan, 20155-Indonesia \\ ${ }^{3}$ Pusat Unggulan IPTEK - Kitosan dan Material Maju, J1. Bioteknologi No. 1, Kampus USU - \\ Padang Bulan, Medan, 20155-Indonesia \\ ${ }^{4}$ Department of Chemistry, Faculty of Mathematics and Natural Sciences, Universitas Lampung. \\ Jl. Prof. Sumantri Brodjonegoro No. 1, Bandar Lampung 35141, Lampung, Indonesia \\ *E-mail: m.zulham.effendi@usu.ac.id
}

\begin{abstract}
Raru (Cotylelobium melanoxylon Pierre) bark has been used in the production of traditional alcoholic beverages (called as tuak), especially in North Sumatera, Indonesia. The objective of this research was to evaluate the potency of C. melanoxylon P. bark as an antioxidant and antihyperuricemic. Methanolic extract of C. melanoxylon P. bark was obtained through the maceration process for $48 \mathrm{~h}$ with a yield of $55.2 \%$. The result of phytochemical screening of C. melanoxylon P. bark methanolic extract revealed the presence of several secondary metabolites, i.e. flavonoid, saponin, tannin, and terpenoid. The methanolic extract of $C$. melanoxylon P. bark exhibited an exceptional antioxidant activity (IC50 $=46.44 \mathrm{ppm})$ that determined using DPPH method. This methanolic extract also showed a significant antihyperuricemic activity in male mice that had been induced using chicken liver (CL) $1.25 \mathrm{~g} / \mathrm{Kg}, 2.5$ $\mathrm{g} / \mathrm{Kg}$ and $5 \mathrm{~g} / \mathrm{Kg}$ of body weight. Based on the result, the methanolic extract of $C$. melanoxylon P. bark might have great potential as an antioxidant and antihyperuricemic agent.
\end{abstract}

Keywords: Antioxidant, Antihyperuricemic, Raru bark, Cotylelobium melanoxylon Pierre

(C) RASĀYAN. All rights reserved

\section{INTRODUCTION}

Indonesian tropical forest is known as the resource of a lot of medicinal plants. The utilization of several woody plant species as traditional medicine until today is based on the empirical knowledge obtained from the ancestor. One species of the woody plants is only found in Sumatera Utara, and categorized as an endemic plant, called as raru (Cotylelobium melanoxylon Pierre). As a family of Dipterocarpaceae, $C$. melanoxylon $\mathrm{P}$. is classified as the first class of wood on durability and preservation, this is the reason for the utilization of this wood in building construction by local people.

On the other hand, especially in North Sumatera, C. melanoxylon P. bark is added into tuak to reduce the amount of foam, and it can improve the taste and alcohol content of tuak. As mentioned in the previous paragraph, its categorization as an endemic species, showed that a population decline caused by the forest conversion. People demand C. melanoxylon P. wood and its bark through unsuitable logging method, like clear-cutting, led to the loss of C. melanoxylon P. population. Therefore, before C. melanoxylon P. becomes extinct, the profiling of secondary metabolite and its bioactivities potential is needed to be inventoried. Many researchers already performed the identification of secondary metabolites that play an essential role in their therapeutic effect, i.e. triterpenoid, flavonoid, tannin, and $\beta$-sitosterol which have shown a therapeutic effect for diabetes mellitus ${ }^{1}$. Raru also can be used as antilaxative, antidiabetic, and blood coagulation ${ }^{2}$, its extract can be used to inhibit the increase of glucose in the blood, raru extract also

Rasayan J. Chem., 13(4), 2569-2576(2020)

http://dx.doi.org/10.31788/ RJC.2020.1345942

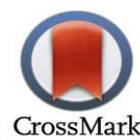


RASĀYAN J. Chem.

Vol. 13 | No. 4 |2569-2576| October - December | 2020

can be used to bind triglyceride ${ }^{3}$. However, from many studies, there is no study yet that utilized raru extract as antihyperuricemic agent. The presence of those secondary metabolites already known can be used as antihyperuricemic agent through the inhibition of xanthine oxidase $\mathrm{e}^{4}$.

Nowadays, synthetic medicine is dominating the market, including for the medicine of hyperuricemia, the common one is allopurinol [1 H-pyrazolo (3,4-d)-pyrimidin-4-01] that is an inhibitor of xanthine oxidase (XO). Based on the biotransformation process of allopurinol, after $24 \mathrm{~h}, 80 \%$ of allopurinol will be excreted in the urine in the form oxypurinol ${ }^{5}$. As XO inhibitor, at low concentration allopurinol could act as a competitive inhibitor of $\mathrm{XO}$, but at higher concentration, it acts as a non-competitive inhibitor. In the clinical trial, allopurinol showed several side effects, i.e. hypersensitivity reaction/ allergy, increase in the amount of 6-mercaptopurine, and nephropathy ${ }^{6}$. To avoid those side effects of any synthetic drug, many people try to use herbal medicine obtained from one or more plant extracts.

Based on empirical therapy and supported with experimental research, C. melanoxylon P. bark showed an antidiabetic agent ${ }^{7}$. The state of the art of that research was about the potential activity of the $C$. melanoxylon P. bark's secondary metabolites as an antidiabetic agent. Supported with the literature reviews, the most of secondary metabolite that showed a bioactivity potency, i.e. antidiabetic, has potency as an antioxidant, i.e. $\beta$-sitosterol and flavonoid ${ }^{8,}$. . The secondary metabolite that has a significant antioxidant activity is assumed can have new bioactivities potential. To the best of our knowledge, no one has ever conducted a study about $C$. melanoxylon $\mathrm{P}$. and its bioactivity as antioxidant and antihyperucemic agent. Consequently, the objective of the present study was to determine the secondary metabolites that available in the C. melanoxylon P. bark and to evaluate its potency as antioxidant and antihyperuricemic agent.

\section{EXPERIMENTAL}

\section{Material and Methods}

C. melanoxylon P. bark was obtained from Berastagi, Karo District, North Sumatera, Indonesia. Methanol and DPPH were purchased from Sigma Aldrich. Allopurinol was obtained from PT. Triman Pharmaceutical Industry.

\section{Extraction of $C$. melanoxylon P. bark}

C. melanoxylon P. bark with a water content of less than $15 \%$ was dried, milled and sieved (100 mesh). A total of $400 \mathrm{~g}$ of $C$. melanoxylon $\mathrm{P}$. bark was macerated using $3 \mathrm{~L}$ of methanol for $48 \mathrm{~h}$ and filtrated. The obtained residue was macerated several times using methanol until no color change was observed. The obtained filtrate was then evaporated using a rotary evaporator until the concentrated extract of methanol was obtained. The yield of extract was determined using the equation below:

$$
\text { Yield }(\%)=\frac{\text { Mass of concentrated extract }}{\text { Mass of simplisia }} \times 100 \%
$$

\section{Phytochemical screening of $C$. melanoxylon $P$. bark}

The crude methanolic extract of $C$. melanoxylon P. bark was tested for the presence of tannin, terpenoid, alkaloids, saponins, and flavonoids. The qualitative results are expressed as $(+)$ for the presence and $(-)$ for the absence of phytochemicals.

\section{Tannin}

A few drops of $5 \% \mathrm{FeCl}_{3}$ was added into the methanolic extract of C. melanoxylon P. bark. Black coloration was taken as a positive result of tannin.

\section{Terpenoid}

The presence of terpenoid in the methanolic extract of C. melanoxylon P. bark was determined using TLC method and sprayed with $1 \% \mathrm{CeSO}_{4}$. The formation of reddish-brown color indicated terpenoid.

\section{Alkaloid}

Methanolic extract of C. melanoxylon P. bark was divided into three equal parts. To the first part of the extract, Bouchardat's reagent was added, a brown precipitate showed the presence of alkaloid. The 
RASĀYAN J. Chem.

Vol. 13 | No. 4 |2569-2576| October - December | 2020

second part of the extract was reacted with Meyer's reagent. The formation of white precipitate indicated alkaloid. At the last part of the extract, Dragendorff reagent was added, an orange-red precipitate showed the presence of alkaloid.

\section{Saponin}

The methanolic extract of $C$. melanoxylon P. bark was shaken with distillate water. The presence of frothing indicated saponin.

\section{Flavonoid}

Ethyl acetate containing few drops of $\mathrm{FeCl}_{3}$ was added into the methanolic extract of $C$. melanoxylon $\mathrm{P}$. bark, the formation of yellow color indicated flavonoid.

\section{Antioxidant Activity}

Briefly, $1 \mathrm{~mL}$ of DPPH working solution $(0.3 \mathrm{mM})$ was added into $2.5 \mathrm{~mL}$ of methanolic extract of $C$. melanoxylon P. bark (40 ppm). The solution was kept in dark condition for $30 \mathrm{~min}$, and the absorbance was measured at $517 \mathrm{~nm}$. The above method was repeated for the other concentration of $C$. melanoxylon P. bark, i.e. 0, 60, 80 and $100 \mathrm{ppm}$. The inhibition percentage was determined using the equation below:

$$
\text { Inhibition }(\%)=\frac{\text { Control Abs-Sample Abs }}{\text { Control Abs }} \times 100 \%
$$

\section{In-vivo Evaluation of Anti-hyperuricemia Effect}

Mice with a bodyweight of $30 \mathrm{~g}$ were raised for seven days to allow them to acclimate to the environment. Hyperuricemia was induced into the mice by administration of chicken liver (CL). Mice were randomly divided into five groups for treatment: G1 was a negative control (CL group), G2 was a positive control (CL + allopurinol group), G3 was $\mathrm{CL}+1.25$ group, $\mathrm{G} 4$ was $\mathrm{CL}+2.5$ group, and G5 was $\mathrm{CL}+5$ group. For the comparative study, the dosages of methanolic extract of C. melanoxylon P. bark was variated into $1.25,2.5$ and $5 \mathrm{~g} / \mathrm{KG}$ body weight. The uric acid content of blood was determined using Autocheck. Blood was collected from the tail vein of mice on days 7, 14, 21 and 28.

\section{Extraction}

\section{RESULTS AND DISCUSSION}

After maceration process of C. melanoxylon P. bark (400 g) and evaporation of the organic solvent, the obtained crude extract was about $221.06 \mathrm{~g}$ and equivalent with $55.2 \%$ of yield. The highest number of yields indicated the effectivity of methanol as a solvent for the maceration process. The other advantages of methanol in the extraction process are (i) to separate the methanol from the sample done in low relative temperature. This statement implies the chemical structure stability of secondary metabolite. (ii) methanol can extract all kind of secondary metabolite which have polar, semi-polar and non-polar structures. This statement supports the research result conducted by Jin et al ${ }^{10}$, claiming that the methanol extract has a most significant antioxidant activity than water-based extract.

\section{Phytochemical Screening}

The phytochemical screening of the crude methanolic extract of $C$. melanoxylon P. bark revealed the presence of several secondary metabolites, i.e. flavonoid, saponin, tannin, and terpenoid as showed in Table-1. This obtained data was similar to the previous study that found the presence of tannins, flavonoids, triterpenoids and $\beta$-sitosterol. On the other hand, Vatica pauciflora, also known as raru that contained flavonoids, triterpenoids, and $\beta$-sitosterol ${ }^{1}$.

Based on the above result, the detected secondary metabolite group is known to have medicinal importance. In the previous study, saponin and terpenoid showed biological activities, i.e. anticarcinogenic, analgesic, antioxidant activity, antiviral, antifungal agents, anti-inflammatory and cytotoxic activities ${ }^{11-13}$. Similarly, tannin as the most considerable constituent among the secondary metabolites found in plant species is known to have antibacterial and antioxidant ${ }^{14}$. Another phytochemical called flavonoid has several bioactivities as antioxidant, anti-inflammatory, antibacterial, 
RASĀYAN J. Chem.

Vol. 13 | No. 4 |2569-2576| October - December | 2020

antiviral, and anticancer ${ }^{15}$. Based on these secondary metabolites found in raru, there is a big chance to develop raru as antioxidant and antihyperuricemic agent, especially C. melanoxylon P.

Table-1: Phytochemical Screening Result of the Crude Methanolic Extract of C. melanoxylon P. Bark

\section{Antioxidant Activity}

\begin{tabular}{c|c|c}
\hline Secondary Metabolite & Reagent & Result \\
\hline Alkaloid & Bouchardat & - \\
\hline & Meyer & - \\
\hline & Dragendorf & - \\
\hline Flavonoid & $\mathrm{FeCl}_{3}$ & + \\
\hline Saponin & Distllate water & + \\
\hline Tannin & $5 \% \mathrm{FeCl}_{3}$ & + \\
\hline Terpenoid & $1 \% \mathrm{CeSO}_{4}$ &
\end{tabular}

The antioxidant activity could show the potential of $C$. melanoxylon $\mathrm{P}$. bark extract to scavenge the free radical molecule, i.e. DPPH. In the present study, the crude methanolic extract of C. melanoxylon P. bark showed the ability to reduce the concentration of free radical molecules with the IC50 of $46.44 \mathrm{ppm}$. Table-2 shows that at $100 \mathrm{ppm}$ of concentration of crude methanolic extract exhibited maximum inhibition of DPPH, i.e. $88.48 \%$.

Table-2: The Antioxidant Activity of C. melanoxylon P. Bark

\begin{tabular}{|c|c|c|c|c|}
\hline No & Concentration (ppm) & Absorbance & $\begin{array}{c}\text { Inhibition } \\
(\%)\end{array}$ & $\mathrm{IC}_{50}(\mathrm{ppm})$ \\
\hline 1 & 0 & 0,8918 & 0,0000 & \multirow{5}{*}{46,44} \\
\hline 2 & 40 & 0,3994 & 55,2142 & \\
\hline 3 & 60 & 0,2976 & 66,6293 & \\
\hline 4 & 80 & 0,1594 & 82,1260 & \\
\hline 5 & 100 & 0,1027 & 88,4840 & \\
\hline
\end{tabular}

The IC50 of the crude methanolic extract of $C$. melanoxylon P. bark showed a potential activity as a potent antioxidant. The presence of several groups of secondary metabolites, i.e. flavonoid, saponin, tannin, and terpenoid could induce that vigorous antioxidant activity of the crude extract. The presence of tannin and flavonoid in crude methanolic extract of $C$. melanoxylon P. bark can be the main reasons for this vigorous antioxidant activity. Tannin is known as a polymer constructed by several kinds of flavonoid and phenolic compounds. Many researchers reported that phenolic and flavonoid compounds commonly have antioxidant activity; several of them showed vigorous activities. Based on literature reviews, the phenolic compound has four classes, i.e. flavonoid (catechin and quercetin), phenolic acid (gallic, caffeic, rosmaricin acid and protocatechuic), colatile oil (carvacrol, menthol, eugenol and thymol), diterpenes (carnosic acid and carnosol) ${ }^{16}$. In several studies, the antioxidant activity of the phenolic group, especially flavonoid, depends on many factors, i.e. the position of the hydroxyl group and the presence of glucan. As described by Russo ${ }^{17}$, the degree of hydroxylation and the position of the hydroxyl group in the B ring will influence the antioxidant activity of flavonoid. The presence of hydroxyl group at 3', 4', 5' of ring $\mathrm{B}$ showed an excellent antioxidant activity due to the presence of $\mathrm{C}=\mathrm{C}$, the hydroxyl group at $\mathrm{C}-3$ of ring $\mathrm{C}$, and glucan ${ }^{18}$. The presence of glucan and the number of glucans in the main structure of flavonoid gave a significant effect to the antioxidant activity of quercetin and kaempferol, that used as the model. In that study, quercetin had the highest antioxidant activity compared to kaempferol and their glycon. The increase in glucan's number resulted in a decrease in antioxidant activities. Also, the kind of glucan gave a significant effect to the antioxidant activity, i.e. quercetin-3-O-galactoside (TEAC $=2.22$ ) and quercetin-3-O-glucoside $(\mathrm{TEAC}=2.15)$.

\section{In-vivo Evaluation of Anti-hyperuricemia Effect}

The transformation of xanthine into uric acid due to the activation of $\mathrm{XO}$ can induce the hyperuricemia condition (Fig.-1a). In Fig.-1, the hyperuricemia condition can be inhibited by disturbing the XO's activity. Logically, the inhibition of XO by chemical interaction can induce a decrease of uric acid in the blood. In practice, the utilization of allopurinol can inhibit the XO's activity (Fig.-1b), but it was obtained 
RASĀYAN J. Chem.

Vol. 13 | No. 4 |2569-2576| October - December | 2020

through a chemical process. Allopurinol can act as a competitive and non-competitive inhibitor; when it was used in a high dose, it will lead to a non-competitive inhibitor. In the biotransformation process, allopurinol will be oxidized by XO to be oxypurinol. As described in many pieces of literature, allopurinol and oxypurinol are an analog compound of xanthine and hypoxanthine, which is a competitor during the uric acid formation ${ }^{5}$.

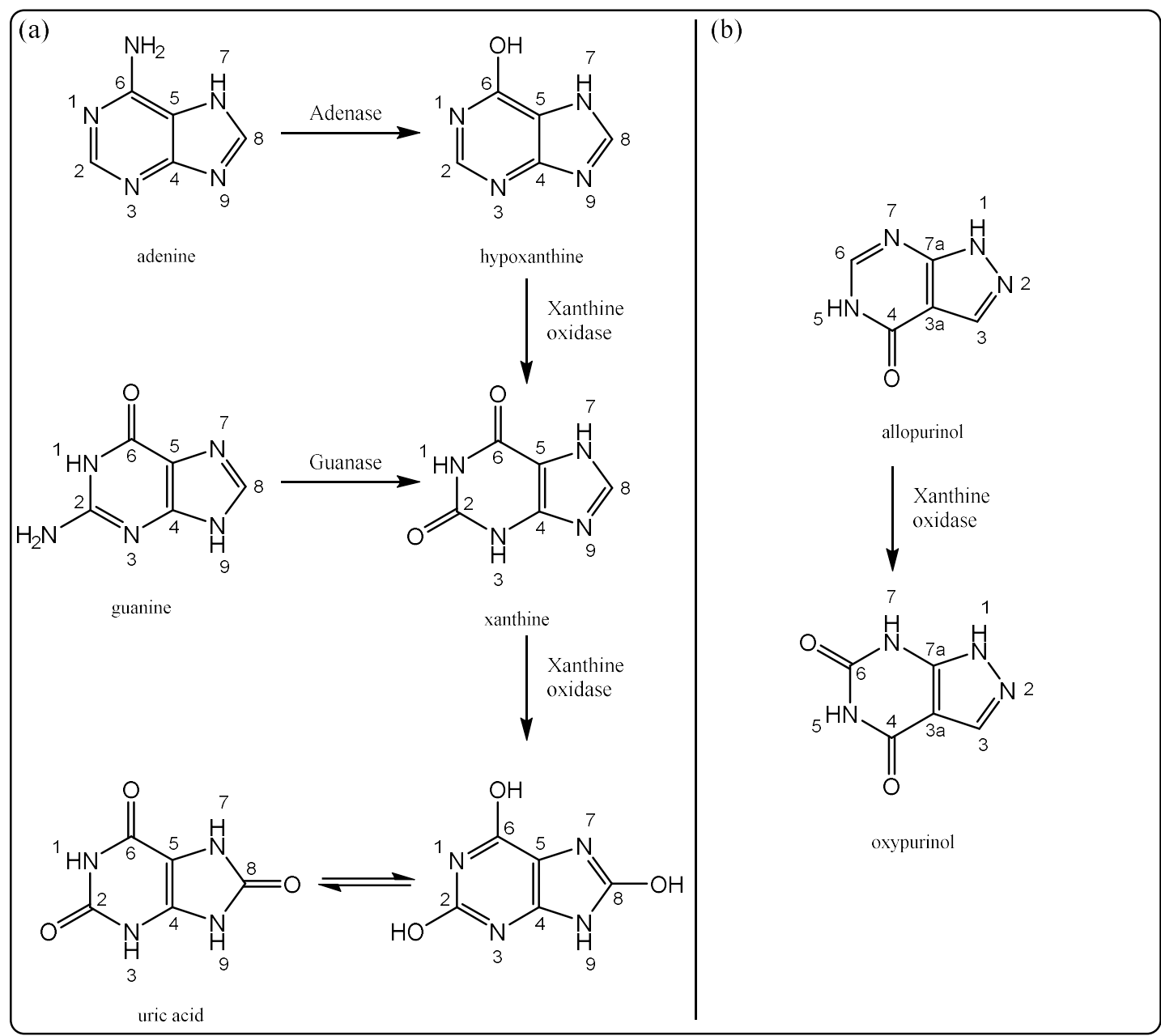

Fig.-1: (a) Biosynthesis of Uric Acid from Purin Mononucleotides (b) Biotransformation of Allopurinol to Oxypurinol $^{5}$

Figure-2 shows the hypouricemic effect of methanolic extract of C. melanoxylon P. bark in CL-induced hyperuricemia mice. The uric acid level of the G1 was significantly increased after induced using CL, indicating successful hyperuricemia induction. After treatment for seven days, in the group that was treated using allopurinol (G2), the uric acid concentration was reduced by approximately $35.42 \%$, compared with the non-treated hyperuricemia group $(\mathrm{p}<0.05)$. Administration of methanolic extract of $C$. melanoxylon P. bark $(1.25,2.5$ and $5 \mathrm{~g} / \mathrm{KG})$ decreased the uric acid concentrations by approximately 2.08 , 15.63 , and $47.92 \%$, respectively, compared with the untreated hyperuricemia control group After three days, the G1 group showed a decrease in the uric acid level; the presence of uricase is the main reason for this result. Uricase is described as an enzyme that able to transform uric acid into allantoin that is easily soluble in water ${ }^{19}$. This transformation indicates the uric acid will quickly leave the mice body during the excretion process as allantoin and found in mice's urine.

The presence of several secondary metabolites in the methanolic extract of C. melanoxylon P. showed a synergy effect to inhibit XO. As the phytochemical result, the methanolic extract of C. melanoxylon $\mathrm{P}$. 
RASĀYAN J. Chem.

Vol. 13 | No. 4 |2569-2576| October - December | 2020

bark contains several secondary metabolic, i.e. flavonoid, saponin, tannin, and terpenoid. Based on the literature and previous study, the utilization of secondary metabolites as hypeouricemia agent has a vigorous activity to inhibit XO. ${ }^{20-25}$ This result is supported by a study conducted by Pasaribu et $\mathrm{al}^{26}$, in the in-vitro study, in which $C$. melanoxylon P. bark can inhibit $\alpha$-glucosidase. The previous study confirmed the presence of 4-Glucosyl-3,4',5-trihydroxystilbene in C. melanoxylon P. as a bioactive component playing an essential role in inhibiting XO.

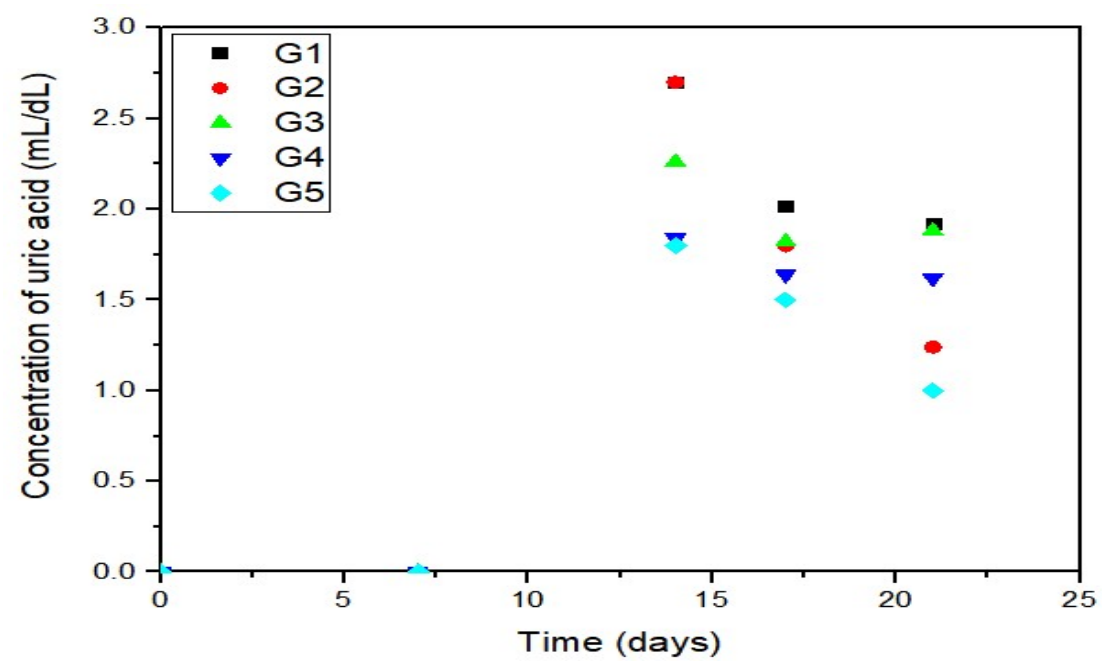

Fig.-2: Hypouricemia Effect of C. melanoxylon P. Bark in Male Mice

The histological analysis of mice kidneys also supported the effect of raru extract to decrease the uric acid content. The study showed a direct correlation between uric acid content and the damage on the kidney. ${ }^{27}$, ${ }^{28}$ Based on Fig.-3, the histological studies showed a significantly difference on the mice's kidney after treated with varied dosages of extract. In the hyperuricemia group with and without extract treatments, the kidney showed symptoms of kidney dysfunction, i.e. hemorrhage (A), glomerulus reduction (B), proximal tubule narrowing (D), and necrosis (especially karyolitic, C1). This data is supported by the previous studies that confirmed the hyperuricemia condition could cause the dysfunction of the kidney. Typically, this condition is associated with segmental glomerulosclerosis and tubular atrophy/interstitial fibrosis ${ }^{29}$. In other treatment with allopurinol, the histological did not show the indication of proximal tubule narrowing, but it showed the formation of necrosis, that was karyolitic (C1) and pyknosis (C2). The use of herb extracts also can be used to reduce the uric acid content, i.e. Dioscorea tokoro Makino, by improving renal dysfunction by regulating renal urate transporters in hyperuricemia rats. ${ }^{30}$

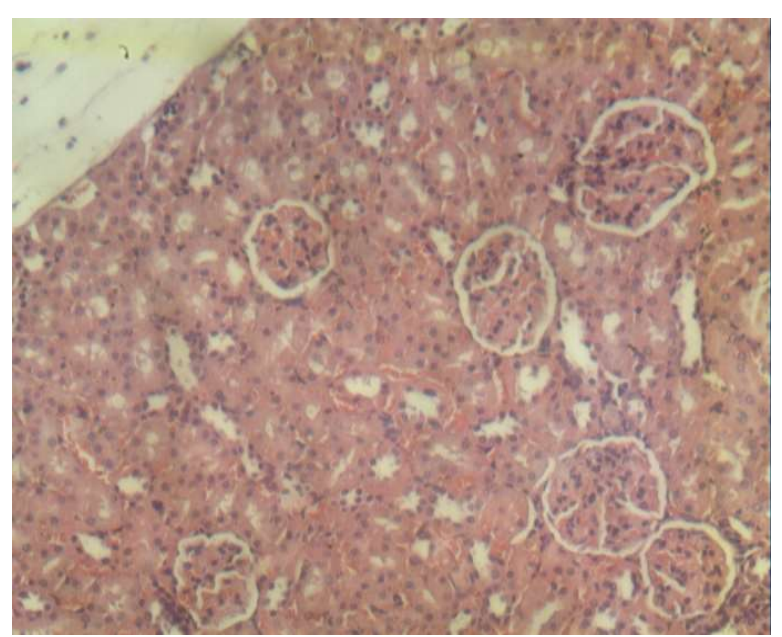

a. Normal mice's kidney

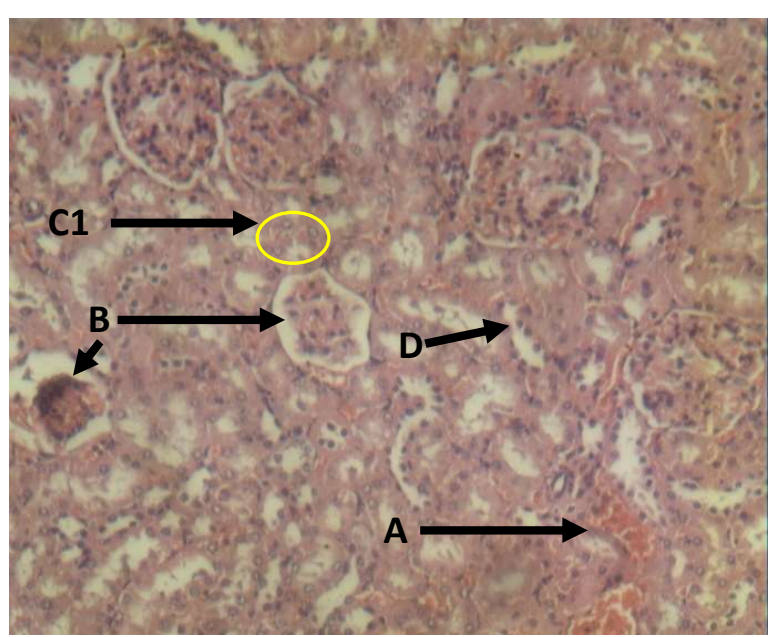

b. Hyperuricemia mice's kidney 
RASĀYAN J. Chem.

Vol. 13 | No. 4 |2569-2576| October - December | 2020

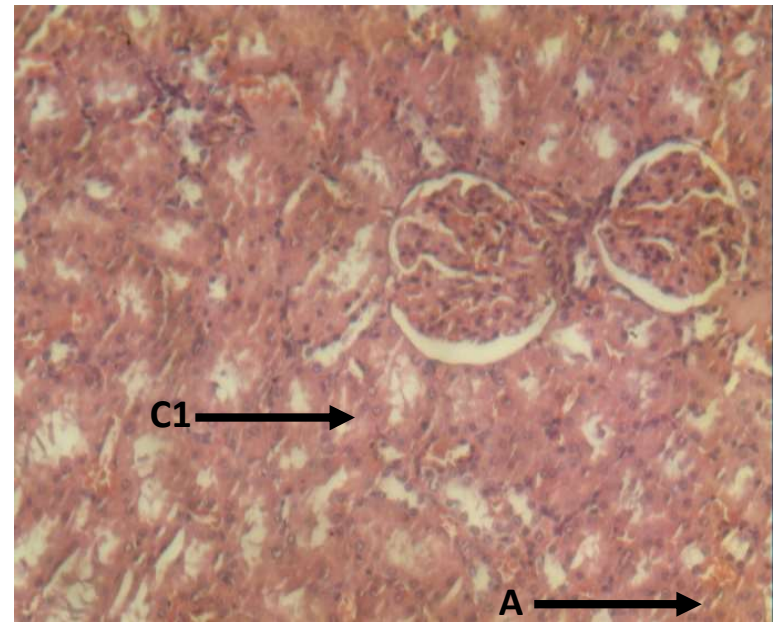

c. Allopurinol

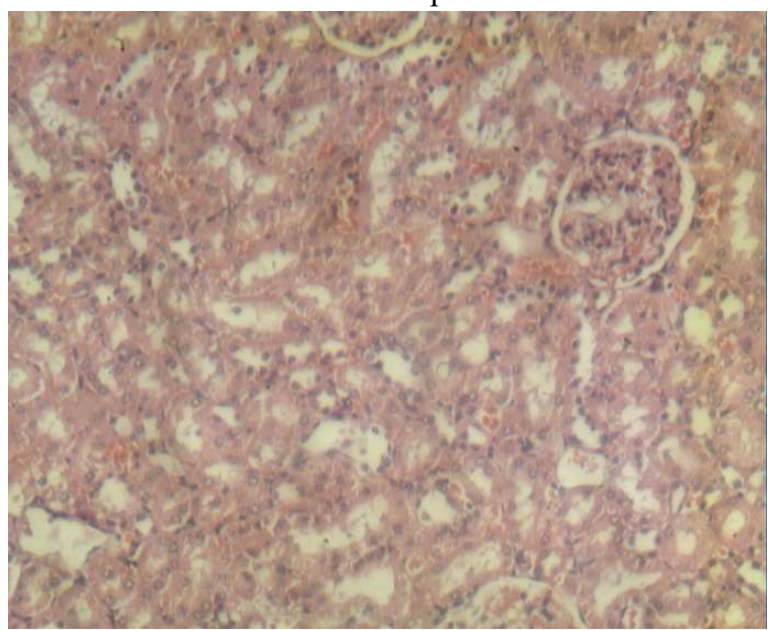

e. C. melanoxylon P. bark $2.5 \mathrm{~g} / \mathrm{KG}$

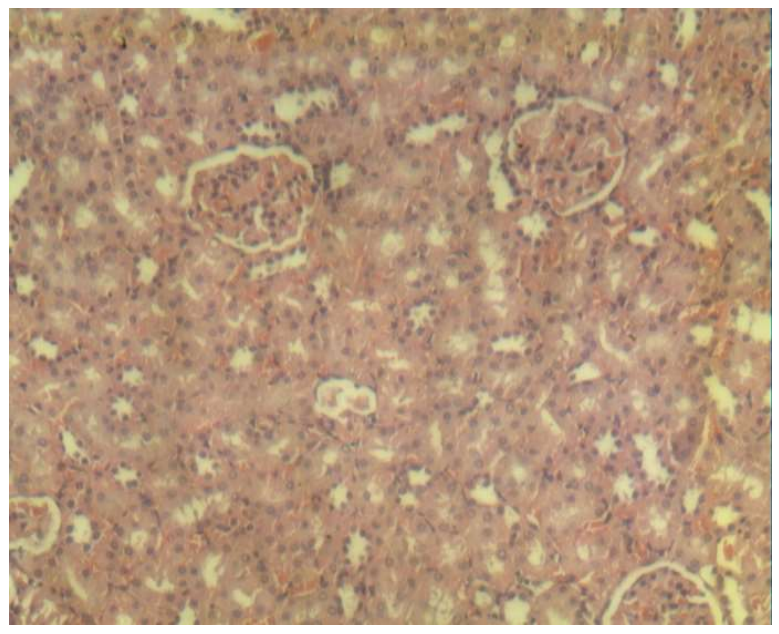

d. C. melanoxylon P. bark $5 \mathrm{~g} / \mathrm{KG}$

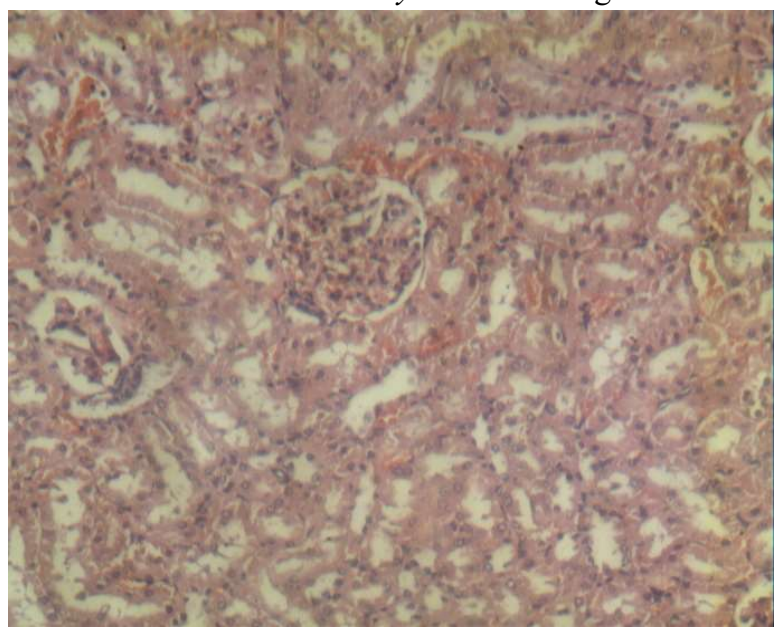

f. C. melanoxylon P. bark $1,25 \mathrm{~g} / \mathrm{KG}$

Fig.-3: Histological Analysis of Several Group Mice before and after Treatment

\section{CONCLUSION}

The obtained result concludes that the crude methanolic extract of $C$. melanoxylon P. bark has several secondary metabolites, i.e. flavonoid, saponin, tannin, and terpenoid. The presence of those secondary metabolites gives an impact as the potent antioxidant activity with $\mathrm{IC}_{50}$ of $46.44 \mathrm{ppm}$. As a powerful antioxidant source, crude methanolic extract of C. melanoxylon P. bark also shows a bioactivity potential as antihyperuricemic agent. In-vivo studies of mice exhibit an excellent result of reducing the uric acid content in the blood of mice fed with crude methanolic extract ( $5 \mathrm{~g} / \mathrm{Kg}$ body weight).

\section{ACKNOWLEDGEMENT}

This research was supported by the Ministry of Research, Technology and Higher Education through the scheme Penelitian Dasar Unggulan Perguruan Tinggi (PDUPT) grant number 234/UN5.2.3.1/PPM/KP$\mathrm{DRPM} / 2019$.

\section{REFERENCES}

1. M. Silalahi, International Journal of Science and Research, 8(6), 622(2019), DOI: 10.21275/ART20198025

2. A. Susilowati, K.S. Hartini, D. Elfiati, H.H. Rachmat, Y.S. Kusuma, M.Z.E. Sinaga and T. Suhartati, Biodiversitas Journal of Biological Diversity, 21(2), 724(2020), DOI:10.13057/biodiv/d210239

3. H. Matsuda, Y. Asao, S. Nakamura, M. Hamao, S. Sugimoto, M. Hongo, Y. Pongpiriyadacha and M. Yoshikawa, Chemical and Pharmaceutical Bulletin, 57(5), 487(2009), DOI:10.1248/cpb.57.487 
RASĀYAN J. Chem.

Vol. 13 | No. 4 |2569-2576| October - December | 2020

4. T. Khammee, A. Rattanapittayapron, C. Rangjaroen, A. Jaratrungtawee and M. Kuno, Rasayan Journal of Chemistry, 12(4), 2273(2019), DOI:10.31788/RJC.2019.1245412

5. G.A.C. Murrell and W.G. Rapeport, Clinical Pharmacokinetics, 11(5), 343(1986), DOI: $10.2165 / 00003088-198611050-00001$

6. E. Fels and J.S. Sundy, Current Opinion in Rheumatology, 20, 198(2008), DOI:10.1097/BOR.0b013e3282f4eff5

7. R.O.P. Situmorang, A.H. Harianja and J. Silalahi, Indonesian Journal of Forestry Research, 2(2), 121(2015), DOI:10.20886/ijfr.2015.2.2.121-130

8. F. Utari, A. Itam, Syafrizayanti and M. Efdi, Rasayan Journal of Chemistry, 13(2), 796(2020), DOI: $10.31788 /$ rjc. 2020.1325547

9. K. Swarnalatha, C.H.V.K. Babu and B.H. Babu, Rasayan Journal of Chemistry, 12(2), 907(2019), DOI: $10.31788 /$ rjc.2019.1225168

10. T.Y. Jin, K. Saravanakumar and M.H. Wang, Biocatalysis and Agricultural Biotechnology, 13, 186(2018), DOI: 10.1016/j.bcab.2017.12.010

11. B. Singh and R.A. Sharma, 3 Biotech, 5(2), 129(2015), DOI:10.1007/s13205-014-0220-2

12. S.D. Desai, D.G. Desai and H. Kaur, Pharma Times, 41(3), 13(2009).

13. V.P. Sülsen, E. Lizarraga, N.Z. Mamadalieva and J.H.G. Lago, Evidence-based Complementary and Alternative Medicine, 2017, 6196198(2017), DOI:10.1155/2017/6196198

14. G. Maisetta, G. Batoni, P. Caboni, S. Esin, A.C. Rinaldi and P. Zucca, BMC Complementary and Alternative Medicine, 19(1), 1(2019), DOI:10.1186/s12906-019-2487-7

15. S.C.Tiwari and N. Husain, Indian Journal of Scientific Research, 12(2), 193(2017).

16. B. Shan, Y.Z. Cai, M. Sun and H. Corke, Journal of Agricultural and Food Chemistry, 53(20), 7749(2005), DOI: $10.1021 / \mathrm{jf051513y}$

17. D. Russo, Journal of Pharmacognosy \& Natural Products, 4(1), 1000e109(2018), DOI: $10.4172 / 2472-0992.1000 \mathrm{e} 109$

18. G.W. Plumb, K.R. Price and G. Williamson, Redox Report, 4(1-2), 13(1999), DOI: $10.1179 / 135100099101534684$

19. F.W. Aprillinda, D. Paramasari and W. Brian, Bali Medical Journal, 7(2), 323(2018), DOI: $10.15562 / \mathrm{bmj} . \mathrm{v} 7 \mathrm{i} 2.878$

20. P.L. Owen and T. Johns, Journal of Ethnopharmacology, 64(2), 149(1999), DOI:10.1016/S03788741(98)00119-6

21. G.L. Chen, W. Wei and S.-Y. Xu, The American Journal of Chinese Medicine, 34(1), 77(2006), DOI: $10.1142 / \mathrm{s} 0192415 \times 06003655$

22. B. Omar, N. Mohamed, R. A. Rahim and H. A. Wahab, In Proceeding of World Congress on Medical Physics and Biomedical Engineering 2006, Seoul, Korea, pp.178-182(2007), DOI:10.1007/978-3540-36841-0_53

23. A. Roohbakhsh, J. Shamsara, M.H. Khayyat and G. Karimi, Pharmacologyonline, 3, 1031(2009).

24. H.F. Al-azzawie and A.A. Samah, International Journal of Advanced Research, 3(10), 1033(2015).

25. L. Zhu, Y. Dong, S. Na, R. Han, C. Wei and G. Chen, Biomedicine and Pharmacotherapy, 93, 88(2017), DOI: 10.1016/j.biopha.2017.06.022

26. G. Pasaribu, W. Syafii and L.K. Darusman, Indonesian Journal of Forestry Research, 8(1), 32(2011), DOI: $10.20886 /$ ijfr.2011.8.1.32-49

27. C.W. Tsai, S.Y. Lin, C.C. Kuo and C.C. Huang, PLoS One, 12(1), e0170393(2017), DOI: 10.1371/journal.pone. 0170393

28. O.S.P. Sah and Y.X. Qing, Nephro-Urology Monthly, 7(3), e27233(2015), DOI: 10.5812 /numonthly.7(3)2015.27233

29. S. Fan, P. Zhang, A.Y. Wang, X. Wang, L. Wang, G. Li and D. Hong, BMC Nephrol, 20(1), 95(2019), DOI:10.1186/s12882-019-1275-4

30. Y. Fei, D. Ye, X. Fan and F. Dong, Tropical Journal of Pharmaceutical Research, 15(9), 1883(2016), DOI: $10.4314 /$ tjpr.v15i9.10

[RJC-5942/2020] 